\title{
ELITE FORMATION AND ELITE BONDING: SOCIAL STRUCTURE AND DEVELOPMENT IN DURBAN
}

\author{
Shannon Moffett and Bill Freund \\ University of Natal, Durban ${ }^{1}$ \\ freund@und.ac.za \\ shannonmoffett@webmail.co.za
}

Economic development is never a process that transpires outside of definite social contexts. The particular strengths and weaknesses of different economic forces and structures inherent in any concrete historical situation and the trajectories which economic actors will pursue cannot be deduced from universal objective formulas derived from "best practice". This paper posits that the perspective and possible trajectory of action of specific urban elites will have a powerful, if not determining interest, on the course of urban development. Development has in fact been theoretically linked with elite theory since the heyday of modernisation ideology when it was assumed that suitably committed elites would be the agents of modernisation in backward countries once they had had their reckoning with traditional elites. ${ }^{2}$ In less theoretical writing, independence for the colonies was assumed to be driven and directed by elites who would hopefully be the key social, political and economic transformers. ${ }^{3}$ This perspective seems naïve and somewhat circular today but we feel that a return to the question of elites may be a necessary exercise; the concept is far from passé.

Why elites? The case study we are examining, that of the large South African port city of Durban, clearly operates as a nexus of capitalist activity. Can one not assess Durban in terms of the plans of the capitalist class, or its most powerful agents, that is to say, the

\footnotetext{
${ }^{1}$ Shannon Moffett is a Masters student in Development Studies and Bill Freund is Professor of Economic History.

${ }^{2}$ An alternative approach was to attempt to turn traditional elites into modernizers through the Indirect Rule philosophy of the British or some equivalent.

3 "Above all, the spread of education presaged the appearance of an intelligentsia which would be capable of influencing the semi-literate masses. As Macauley had foreseen in India a century earlier, education was the progenitor of self-government”. (Hatch, 1965, 27)
} 
representatives of important national and trans-national corporations seeing that this is the case? $^{4}$

This paper suggests that such a view would also be too simple from two respects. First of all, capitalists cannot act directly in terms of structuring the city to their liking. They have to contend with what we shall term a political elite, politicians who represent the democratic intrusion of other social layers into the way the city develops. This political elite, for the purposes of the study, will be defined largely in terms of their position vis-àvis the City Council. In addition, they have to operate in terms of a city bureaucracy, which has acquired very substantial expertise and practical autonomy over time. This bureaucracy may be said to pursue its own vision, its own interests, to a significant extent. It seems appropriate and convenient to look at the business elite, the political elite and the administrative elite as distinct actors precisely in order to examine their interactions.

However, the elite, including the economic elite, are themselves internally divided in important ways. Durban has evolved into a city that is notably deficient in the creation of a distinct, locally-bound bourgeoisie. (McCarthy, 2001) While there are business interests bound up primarily in the fate of the city, most big economic operators are in effect branch plant managers who are subject to decisions taken outside the area. Indeed, Padayachee has shown that most development finance in the private and public sectors has in recent historic times, come from outside Durban. (Padayachee, forthcoming)

Second, there are ethnic/racial divisions of significant importance within what might at first sight be termed a ruling class. Indeed until the national elections of 1994, the city was specifically run in the interests of a minority racial group, the whites, as part of the colonial and settler history of South Africa. By contrast with the rest of the country, however, Afrikaners were a relatively small minority within the white population of Durban and the

\footnotetext{
${ }^{4}$ The one important group one could describe as an elite completely outside capitalism are the "traditional" chiefs whose territories are now included in the vastly expanded Unicity boundaries. We are not going to consider them in this essay. But see, in this same collection the paper by Sultan Khan and Benoit Lootvoet, "Tribal Authority and Service Delivery in the Durban Uni-city".
} 
province of Natal; the principal local actors in all three spheres generally did not come from the ruling political party and belonged to the English-speaking white population, a minority within a minority. A second particular feature of Durban was the presence of more than sixty per cent of the South African population of Indian descent. Victims of discrimination, Indians were nonetheless defined as a racial group separate from Africans and they had different, and generally more, access to rights and opportunities. From the nineteenth century, there was an important Indian business elite in Durban, first commercial and eventually also industrial, that had no real comparison with other racial groups of colour elsewhere in the city or country.

Amongst the elite that developed out of the majority African population, particularly from the 1960s but far more dramatically after the political democratisation of South Africa, there are Zulu speakers and others, both individuals linked to the accommodative Inkatha Freedom Party history and others linked to the once-exiled African National Congress with its history of militant resistance to the old state. In the post-apartheid context, once excluded individuals from all these different starting points are given opportunities and actively encouraged through policies such as Affirmative Action to become leaders in the economic and political world; some are successful in forging the informal social networks to facilitate this process. ${ }^{5}$ Given these divisions, the problems involved in understanding Durban in terms of elites become more comprehensible.

The hypothesis of this paper is that the successful interpenetration and discourse among elites may be the key to understanding whether particular development trajectories succeed in Durban. Of course, this is an issue that may very legitimately be argued for the whole national scene, for contemporary South Africa. Theoretical approaches to development do indeed provide examples for considering the way such interpenetration has been

\footnotetext{
${ }^{5}$ Research methodology has included examination of primary and secondary material. Interviews have mostly been conducted by Shannon Moffett. Criteria for selecting elite members for interviews will be discussed in her upcoming Masters thesis for the School of Development Studies, University of Natal, Durban. One aspect of primary research has been a systematic study of Affirmative Procurement Policy beneficiaries in the tendering process where directly public patronage of private actors takes place under determined conditions.
} 
fundamental to the construction of particular national capitalist projects. (Evans, 1979) The modern success of the Asian Tigers appears to rest on successful elite cohesion; indeed, following intense and violent struggles, this was the model that emerged in the nineteenth century from Japan, which was internalised in Taiwan, Korea and elsewhere. ${ }^{6}$

All the elite fractions that have been mentioned function actively in terms of provincial and national networks. However, we are assuming here that it is worthwhile understanding elite activities and elite interactions at the level of the city and of urban development. Freund has already written that the relationship between the business elite and the city bureaucracy in white Durban was decisive in many aspects of the form taken by the economic development of the city. (Freund in Freund \& Padayachee, forthcoming) As the American political scientist John Purcell, writing on Durban in the 1970s and who has influenced our approach, knew well, a powerful initiative from within the bureaucratic elite can be critically important. (Purcell, 1974; Caro, 1975)

Our context, moreover, is one of the existence of something of a crossroads, if not a crisis. A recent report commissioned by the Economic Development Department of Metro Durban from a prestigious international consultancy has suggested that Durban's development trajectory was sagging. (Monitor Group \& Durban Unicity, 2000) The Monitor report, which may prove to be very influential, uses the Porter paradigm of competitiveness to assess Durban in the context of a changing global economy. The challenge of incorporating a large poor urban population mainly on the periphery, given dependence on stagnant and declining industries, is not being met very effectively. "If Durban carries on along its current path, it will slide toward real economic crisis within the next 10 to 15 years". (Ibid. 22)The city is not in a position to simply coast on autopilot; it had to take new initiatives to keep afloat, let alone advance. Officially, the local government policies of the ANC tasks cities such as Durban with taking key economic initiatives. (South Africa... White Paper on

\footnotetext{
6 "...the hostility between state officials and private entrepreneurs that afflicted the economies of Continental Europe seems to have been largely absent in Japan..."(Landes, 1965, 113)
} 
Local Government) ${ }^{7}$ This assumes close co-operation between private and public sectors, official partnerships but also unofficial bonding between key actors. Thus the success or absence of elite cohesion may be a crucial factor in evaluating the potential for such initiatives.

In our investigation and with this context in mind, we will in particular considered the following questions:

- Who is the elite in Durban?

- On what levels does the elite interact?

- What forums exist for this interaction?

- Who drives this process for economic development - the economic or the political elite?

- To what extent are the new elite major players or is the old (and essentially white) elite still really dominant?

- Who is being excluded from this process and with what consequences for the development of the city?

\section{Elites and theory}

Theory about elites is a mainstay of sociology. Max Weber's concern for status and his interest in bureaucracies, in modern politics as a profession and other social questions makes him a particularly salient writer on elites. The Marxist tradition places a strong weight on questions of ownership within capitalist society but it requires supplementation

\footnotetext{
${ }^{7}$ Local government should thus be "...namely exercising municipal powers and function in a manner which maximises their impact on social development and economic growth, playing an integrating and coordinating role to ensure alignment between public[including all spheres of government] and build private investment within the municipal area, democratising development, and building social capital through providing community leadership and vision, and seeking to empower marginalized and excluded groups within the community". (South Africa...p.8)
} 
through understanding how actual power is effectuated in real situations. ${ }^{8}$ Giddens points to the relatively inflexible way that both Marx and Weber dealt with the potentially very complicated relationship between economic and political power.(Giddens, 1981) From the 1930s, writers such as Berle and Burnham (Berle, 1954; Burnham, 1941) emphasized the importance of a trained layer of management in the actual determination of business operations, given the increasing dominance of very large, internationally-minded firms. This work can be supplemented by that of Coase, whose interest in the diffusion of knowledge within the firm as a marker of efficiency, has made him the intellectual progenitor of the new institutional economics.(Coase, 1937)

From this comes the view that effective and powerful social and economic structuration go hand in hand in modern societies. John Kenneth Galbraith has proposed that the "new industrial state" depends on the marriage of different elites into a single one, a

technostructure with common goals that are internalised from an early point. (Galbraith, 1971) He emphasised particularly that the big, complex firms were so structurally and culturally intertwined with the public sector that discerning separate and overtly conflicting goals was difficult, if not impossible. Crude instances of bribery and direct influence of an improper kind have become the exception rather the glue that holds the system together.

The sociology of modern France has also examined the inter-relationship of an elite, living in close quarters and trained in the same elite institutions, developing a similar outlook whether based in the private or public sector. ${ }^{9}$ This "conspiracy" has been seen as the main force behind the indicative planning typical of pre-1980 (and to some extent, more recent) decision-making. A less flattering view of this process of elite coalescence in the USA was

\footnotetext{
${ }^{8}$ Thus for Bob Jessop, “...the class aspects of the state will be overdetermined by various kinds of non-class relations. The latter comprise private, non-economic relations founded in civil society and 'public' relations among political categories". (Jessop, 1982, 247)

9 “...the state essentially created the new social partners with whom it was to ally... the management of French industrial strategy became a cooperative endeavour between civil servants and industrialists... The interchange reinforced the like-mindedness and mutual dependence of the two sides The most dramatic consequence to follow from this was the growing interpenetration of private management and the civil service... Government policies were creating a kind of technostructure in France, a new social group at the
} 
categorically detailed by C. Wright Mills in The Power Elite. For Mills, "major national power resides in the political, the economic and the military domains". ${ }^{10}$ (Mills, 1956, 6) Mills understood this elite formation process to be a fundamental barrier to the genuine democratisation of industrial society.

American social scientists have been particularly influential in looking at how the interaction of public and private sector elites have helped to shape and re-shape the urban milieu in the twentieth century USA. The pluralist classic, Who Governs? by Robert Dahl specifically compared different elites and looked at the formation of key alliances in the political process of the small American city of New Haven. (Dahl, 1961) Contemporary sociologists, such as Hunter, used this pluralist framework to identify elite members practically through identifying individual reputations, a technique we have found useful in research methodology. (Hunter, 1963) This approach by itself fails to distinguish power relations within the elite nor does it distinguish those members of the elite with a commitment to a particular local economic environment from those without such commitment.

However, it is possible to make use of this approach in deriving the important notion of the growth coalition. (Logan \& Molotch, 1987) The reconstruction- "urban renewal” of the economically exhausted US post-World War II city was usually spearheaded by so-called blue ribbon commissions, which would include top business leaders as well as academics and trade unionists. Their plans would in effect be rubber-stamped by politicians worried about economic decline and in need of the injection of dynamic ideas, especially when accompanied by cash. Such growth coalitions have required the basic commitment of powerful, locally-based business interests. A classic example, built around the corporate world of the Heinz, Mellon interests and a few others, was the reconstruction of central Pittsburgh. (Ferman, 1996) ${ }^{11}$

pinnacle of private and public sector management with a distinct set of shared, attitudes, backgrounds and interests." (Hall, 1986, 168)

${ }^{10}$ Mills in fact drew on analyses of particular towns and cities.

${ }^{11}$ Ferman in turn refers to the regime theory of Stephen Elkin. 
However, it is important to note that these urban renewal projects were not always viable in and of themselves. Large-scale investments to renew downtown Detroit, once the fourth largest city in the USA, have been notoriously unsuccessful.(Herron, 1993) New Haven, a model city in the 1960s, has never recovered from the intensified downturn of the 1970s. Some smaller cities have lacked corporate champions and been unable to find the support needed for investment. ${ }^{12}$ In other cases, but these are not usually investigated, the absence of effective elite alliances, precludes or cancels out development.

It is perhaps even more important to emphasize, even where American trade unions were involved, that growth coalition politics have often been aimed against the poor and the preservation of space that they have found most helpful for survival and sociable living. ${ }^{13}$ Urban renewal has often meant the disappearance of neighbourhoods, homes and jobs. It has been the scourge of progressive urban planners. Ultimately this approach follows the lines laid down by Mills fairly consistently on the scale of the individual city. Growth coalitions tend heavily to be dominated by business interests and other social concerns, at least in the USA, have if anything relied on national political forces to represent a counterweight. (Mollenkopf, 1983) One relatively successful attempt to conceptualise the relationship between different interest groups while stressing the weight of corporate power is the work of Clarence Stone, based on his political economy orientated studies of Baltimore and, especially, biracial Atlanta, which he has termed regime politics.
"What makes governance in Atlanta effective is not the formal machinery of government, but rather the informal partnership between city hall and the downtown business elite. This informal partnership and the way it operates constitutes the city's regime; it is the means through which major policy decisions are made”. (Stone, 1989, 3)

\footnotetext{
${ }^{12}$ For a study of a city where the economic elite had to compromise significantly with trade-union based pressures in part and simply experienced considerable failure in part, see Keil, 1988 and Bennett et al, 1988.
} 
Regime politics seems to be a dynamic and more intellectually viable conceptual basis for analysis than the bland idea of "governance" tied to the apron strings of the World Bank and aid agencies. Stone's work emphasises, however, that in the absence of effective organisation, elites are very likely to triumph over popular interests, even those marked by protest movements, most or all of the time. His account of Atlanta highlighted an era of political transition when the relationship between business and political elites were suddenly in question, a hesitant phase which gave way to renewed business dominance along somewhat altered lines.

Moreover, urban renewal plans, even when left-wing politics have been very influential, (say, in Stockholm) have often based themselves on modernist projects that not only dehumanise but are not necessarily very appropriate to the more flexible and small-scale economic operations characteristic of profitable and expanding sectors of capitalist production and exchange at the start of the twenty first century. (Amin, 1994; Castells, 2000) In most capitalist societies, the need to make big concessions to firms in order to entice investment and boost profit rates has engendered the "private-public partnership" paradigm where the ability of the public sector to make conditions for the private sector has diminished dramatically and the role of the state has been "accepted" as being essentially facilitative only. ${ }^{14}$ In the discourse of the World Bank, there is a [welcome] "...shift in the role of central government from direct providers of urban services and infrastructure...to creating a regulatory and financial environment in which enterprises, households and community groups can play an increasing role in meeting their own needs." (World Bank, 1991) Explained in terms of the limited capacity of the state to act in its own right, this way of reasoning of course excludes most consideration of intensifying or increasing that capacity. Where civil society is weak, private actors may be able to intervene dramatically in the contemporary structuration of even a major city, subverting urban planning by the state. (Bredeloup, 2001)

\footnotetext{
${ }^{13}$ This theme dominates Cummings, 1988.
} 
Into this picture, Ferman suggests for American cities that community-based organisations (and we may add in the southern African context, non-governmental organisations) are perhaps the best hope for progressive interventions in this picture. (Ferman, 1993) Patrick Heller, in reviewing research on Brazil and India, has looked at progressive developmentorientated local governments which have benefited from particular political configurations. In Durban, it certainly remains true that the political elite has a strong commitment to "deliver" services and infrastructure to a largely working class electorate despite the indifference or hostility of the business community. This bundle of potentially contradictory perspectives is in fact one reason why Durban is of special interest as a field of study.

Exploring the modus operandi of segments of the Durban elite, their perhaps competing or contradictory agendas and their characteristic forms of inter-reaction may provide a useful context for understanding the potential for urban economic development. ${ }^{15}$ The contemporary policy emphasis on local economic development reflects not just a goal but a can of worms that opens up many questions about the range of possibilities open today. Most of our focus additionally will be on newly forming elites who have yet to be studied with much attention and whose future trajectory will be of increasing importance.

\section{History of Elite Interaction in Durban}

Pillay highlights the fact that since the middle of the nineteenth century, the government in Durban had played an important role in the growth of Durban, particularly in terms of commerce and industry (Pillay, 1994,46). In fact, as Bjorvig discovered, "local business leaders readily established an intimate connection between economic and political power. Many of them used their position on the Durban Town Council...to wield preponderant civic influence and became the driving force in the development of the town." (Bjorvig, 1994, iv). The dominant economic elite was largely involved in local politics, to the extent that many of the mayors and councillors of the time were from the economic elite class.

\footnotetext{
${ }^{14}$ However, this kind of justified scepticism was found on the part of Left writers earlier as well. See Miliband, 1959.
} 
This economic elite engaged primarily in commercial activities, owing to Durban's establishment as a trading centre. The strong relationship between the economic elite and political elite was reinforced by the fact that qualification to become a councilor was based on property ownership. (Ibid. 47).

Thus entrenched in positions of political power, the commercial elite was tasked with the development of the city, often to serve their own interests. Bjorvig provides the example of Mayor Hartley, a leading merchant and economic elite who macadamized Berea road, which had obvious positive implications for this business (Ibid,156). This is but one of numerous such examples of where economic elites in the city used their political power to advance their own vested interests through targeting development initiatives. However, vesting interests in the narrow sense can not be said to underlie all their development initiatives, and vested interests aside, this elite power group did contribute significantly to the development of the city. Whether such interaction can be termed a coalition is debatable because of the extreme cohesiveness of the elite grouping to the extent that the political and economic elite were often represented by the same individuals.

Through continuing development in Durban, the old elite groupings were challenged by a new emerging elite. Politically, the old power group was broken up by the James Commission of 1964, set up to investigate corruption in the council. Purcell sees the significance of this as being a change from patronage style decision making to a more bureaucratic style, (Purcell, 1974, 236). This opened the way for greater participation of business and other interest groups for interactions with the political elites without the stigma of corruption or patronage attached. However, Purcell found that the interactions in the late 1960s between groups such as the Chamber of Commerce, were largely negative in nature, insofar as that their involvement was limited to trying to restrict proposals seen as harmful to their businesses. (Ibid., 172). Importantly, business had important connections to provincial government, and was often able to exert such pressures through these connections rather than through connections with local government. (Ibid., 1974, 4).

\footnotetext{
${ }^{15}$ On this for Britain and the USA, see Useem, 1984.
} 
Despite such impediments, there have been numerous examples of coalition activities in Durban in the twentieth century.

An important feature of local government in Durban, which was to impact significantly on economic development and interactions between the council and business, was the council's speculation in land. "The city authorities became increasingly expert at purchasing, selling and leasing land in order to provide attractive conditions for industry and thus bring employment to the city." (Freund, n.d., 24). Here a degree of negotiations were required between the business and political elite. Land was favourably allocated to some industries which fulfilled the criteria of, for example, job creation, set out by the council. (Ibid., 25). Another significant factor was the establishment of the capital fund. Money for this fund was from sums gathered through moderate rate increases. As well as being used to reduce debt, it was significantly used for investment. This generated funds that allowed for rates to be kept low, a further attraction for investment. (Ibid., 27). Freund found that the nature of the relationship between business and the local government began to change during the 1980s. Where the city had once prescribed the conditions under which business was given access to cheap land, this changed to a relationship based more on a public-private partnership basis. Freund cites the example of the city partnership with Anglo American for the industrial development of the Springfield Flats (Ibid., 26).

This partnership-forming continued into the 1990s, the era of political transition. Pillay attributes such increasing coalition forming initiatives in this period to a number of factors (Pillay 1994, pg. 73). The first is that the economy was ailing. In the case of Durban, this was evinced on the marked decline in key manufacturing sectors. (Ibid., 74). The second factor in the local sense is that "local actors intervened in order to re-assert and secure their influential role in local processes at a time in which there was much uncertainty over a future political dispensation for the country.” (Ibid.,73). Given this, he asserts that these initiatives were meant to both promote economic growth and to restructure the political order on a non-racial basis. (Idem.). The best researched of such initiatives, was “Operation Jumpstart”. Operation Jumpstart was a city led initiative of public and private 
sectors with the primary aim being the promotion of the economy of Durban and for job creation. It was a stated aim of Operation Jumpstart that the initiatives would include all stakeholders and that a compromise of interests would be sought rather than Operation Jumpstart being representative of any singular players. (Ibid., 76). Robinson \& Baldogh found a changing make up of coalition actors in the time leading up to the inception of Operation Jumpstart. Behind the scenes negotiations and compromises resulted in left wing forces being incorporated into planning processes, while the left wing found themselves moving with a process dominated by more conservative state and business interests (Robinson \& Boldogh, 1994, 196). However, it is their conclusion that, despite apparent consensus, business interests still dominated.

Out of Operation Jumpstart came projects such as those centred around the development of Cato Manor, and importantly, the construction of the Durban International Conference Centre (ICC). The ICC is a conference centre with a seating capacity of 7000, which was built through funding of the city. One of the most important facilitating contributions of the building of the ICC was the careful management of city funds. However, the coming together of the representatives of all sectors in the community of Durban with a common vision was seen to be crucial to the final approval of this project. This development has brought many hundreds of thousands of visitors to Durban, and with them, their disposable income for spending in different sectors of the Durban economy. Despite such successes, Operation Jumpstart did have its limitations. Pillay lists these problems as being that it followed primarily a corporatist growth path, was not representative of all interest groups, despite its stated intention to be so, and was confined to limited strategies for growth. (Pillay, 1994, 78). In reality it seems as if Operation Jumpstart was more about business interaction within a framework that existed to co-opt other players into the 'coalition', thus allowing for better realisation of the principal actors'own business interests (Robinson \& Boldogh, 1994,,210). The lack of real commitment on the part of the city was shown by the 1992 Council - Transnet plan for the development of the Point. This planning was made outside of the forums established by Operation Jumpstart. (Robinson \& Boldogh, 1994, 205). However its primary success was in that it was "one of the first attempts at co- 
operative problem-solving in the locality of Durban... [and] ... it represented a bold and imaginative step towards beginning to redress the seemingly insurmountable development problem facing this metropolitan region" (Pillay, 1994, 78). Importantly, other initiatives emerged from this process. One such initiative was the Durban Functional Region (DFR) Development Forum, with participants from a wide range of political parties, government bodies, civic grouping, business associations and other groups, (Ibid., 80), and later, the Greater Durban Marketing Authority.

The fallacies of the existence of a de facto coalition in Durban should at this stage be clear. The dominance of the business sector in this process needs to be further teased out in attempting to highlight who the economic elite in the process of collaboration for economic development. Terry Rosenberg, the chairperson of Operation Jumpstart, was the McCarthy Group Chairperson. ${ }^{16}$ Gordon Hibbert, from Tongaat Hulett Groups, was chairperson of the business group of Operation Jumpstart. Bruce Formsman, from the property group RMS Syfrets was tasked with attracting international investors.

Tongaat Hulett, owners of vast sugar estates north of the city, and especially and more recently, their property development division, Moreland, have played a major role in the forums for economic development of the city of Durban.

"The group activated a planning process that led to the formation of the TongaatHulett's Planning Forum, the revitalisation of its property division in 1988, and finally to the development of the land itself, initially in partnership with the (old) Mt Edgecombe Local Authority. The relationship between Morelands and the local authority was innovative and dynamic - a member of the company's planning division, for example, doubles as the Town Planner for some time"...Tongaat provided (from its own sources) the bridging finance to the local authority to build up the infrastructure. These loans were repaid annually from the

\footnotetext{
${ }^{16}$ This is a company with very substantial Durban interests that has since run into considerable financial difficulties.
} 
rapidly escalating ratable income of the local authority, as development followed the laying down of infrastructures. The company laid out R150m in four years for such infrastructural development...Morelands have been involved in many residential developments as well as being involved in various industrial and commercial developments. "These Tongaat-Huletts-led developments have already radically altered working and living patterns in the city, by halting and then slowly reversing the concentration of economic activity in the southern Durban industrial basin." (Padayachee, n.d.,104-05)

Freund found that Rosenberg and key players from Tongaat Hulett have continued to play important roles in the growth coalition since democracy to "bring together an array of interests and to establish links to key new political actors that will promote issues central to the growth of the city." (Freund, n.d., 43). He further warns that "private-public partnerships can become a mask, if the state is weak, for simply subsidising the initiatives of powerful private political interest.' (Ibid., 50). Here the powerful private interests in Durban would be the large companies, often very connected to national bases. It is the contention of this paper that this is indeed the case of Durban in post-Apartheid South Africa. Due to, amongst other reasons, its existing expertise in coalition involvement this paper asserts that powerful white business still holds a major influencing role in the coalition in the city.

\section{The emergence of a new elite}

Before this paper can move on to examine the new elite in Durban we need to develop a greater understanding of where they come from. Apartheid policy sought to suppress nonwhite members of society from developing socially, politically and economically. However, various commentators have shown that the Apartheid policy in fact encouraged the creation of an elite that would suit their own agendas. However, in South Africa, this process goes back as far as the 1850s--long before the onset of Apartheid as a official policy, where the Cape governor of the time, Sir George Grey built schools to educate the sons of chiefs. This, it was hoped, would ensure alliance of this elite grouping to the 
colonial rulers (Macozoma, 2000, 14). As he further explains, this would also ensure that Christianity was taken by these educated individuals into rural areas (Idem.).

The creation of Bantustans by the Apartheid government from the 1950s further provided opportunities for the consolidation of non-white elite creation. For the system to work, leaders of the Bantustans needed to collaborate with the Apartheid regime. This they did in exchange for various rights and privileges (Idem.) Through this, an economic and political elite in these areas was established and reinforced. The incorporation of traditional leaders into the Apartheid system by this means underpinned the policy of separate development in rural areas. Real challenges were presented however with increasing migration to the cities. Here the policy centred around "attempts at creating a 'privileged' working class and a stable, affluent and collaborative urban petty bourgeoisie", (Nzimande, 1991, 69). This petty bourgeoisie was in the form of a bureaucratic, trading, civil, and from the late 60s onwards, a corporate bourgeoisie. Importantly, as Nzimande reminds us, they were still subjugated and dependent and servicing the designs of the Apartheid policy (Ibid.,70). Nzimande found that there were strong links around the trading and bureaucratic bourgeoisie who used their position to promote their own commercial businesses. The creation of a civil and bureaucratic bourgeoisie was primarily for the management of Bantustans and other non-white areas. Nzimande shows that that the creation of the civil, trading and bureaucratic bourgeoisies were state initiatives aimed at reinforcing their Apartheid policies.

The corporate bourgeoisie, by contrast, were found to be a product of capital rather than the state. Capitalism could hardly be confined to one race as a system. Capital tried to create a black middle class, while at the same time, being mindful not to place the existing elite under threat. Capital and state collided on this issue through legislation such as job reservation (Ibid., 115). At times of labour unrest, capital saw the benefits of having labour under control of their own kind. Thus began the "Induna" system whereby blacks supervised blacks. Most of the corporate bourgeoisie, Nzimande discovered, were therefore to be found in personnel, the department that stemmed ultimately out of the 
"Induna" system.. Thus capital was allowed to keep in touch with labour and able to advance better selection, training and control of African labour. Nzimande states that these moves had little to do with Black advancement and more to do with white capital interests (Ibid.,194) Nonetheless, the emergence of a corporate non-white elite began.

Durban is different from other cities in that it is home to a very large Indian population. Indians, like Africans, were actively hindered in their development by the Apartheid state. Despite some of these restrictions, some Indians managed to develop thriving businesses (Hart \& Padayachee, forthcoming) There were two distinct groups of Indians who arrived on the shores of Natal during the late nineteenth century. The first group were mostly Hindu, and worked as indentured labour on the sugar farms. The other group was predominately Muslim, and were called 'passenger Indians' due to the fact that they paid for their fares on the ships. These individuals, as Hart and Padayachee argue, had merchant experience and international contacts and were consequently able to establish successful businesses. Hart \& Padayachee give the example of the Moosa family falling into this category. In terms of the indentured labourers, many chose to stay after their terms of contract were up. Despite severe restrictions on trading, a class of shopkeepers began to develop (Ibid., 687). They were supplied by the wholesalers, who had arrived in the form of the passenger Indians. So we find stratification amongst the Indian community from the early inception of Indian businesses in Durban. This stratification was along the lines of caste, class, religion, and language. However, policies of the National party encouraged KwaZulu-Natal Indians to maintain a closed corporate community. (Ibid., 684).

Prominent Indian businesses began to flourish in the post-war era thanks partly to the import substitution industrialisation policies of the South African government. The focus of business began to shift from trade to include industry especially in the clothing and textiles industries. (Ibid.,693). Thus, an Indian commercial and industrial elite emerges in Durban. Hart \& Padayachee state that some of these businesses benefited from close political relations with the Apartheid government (Idem). They go on to show that some of 
the Indian businesses that relied on such links are coming under pressure in the postApartheid era.

Other businesses have embraced the new economic climate and are showing great successes. Vivian Reddy, the owner of Edison Power, had links to, and consequently contracts, from the Apartheid government. However, he has survived the transition and been able to extend his interests into the post-Apartheid era. He has diversified his business into various sectors and has cultivated links with foreign investors, particularly those from Malaysia. He has strong links with both the ANC and IFP party leaderships. (Ibid.,706). Hart \& Padayachee highlight the need for Indian businesses in Natal to break with a micro economy outlook that was tied to Apartheid. (Ibid.,697) Hart \& Padayachee show that the most successful and surviving Indian businessmen, who tend more towards the entrepreneurial elite, are those who:

"...have responded with extraordinary successes to the new opportunities of the post-Apartheid era, forming alliances with old white money, black political power, foreign Asian capital, and diaspora connections throughout the world to dominate the home market and more aggressively in foreign markets as well" (Ibid., , 684).

While the Indian elite was faced with pressures preventing their economic advancement, the Black elite was under even greater pressures. One route available to them was the corporate route as discussed by Nzimande. While not without its own limitations, some individuals were able to overcome obstacles to achieve elite status through this route. The prime example here is 'JB' Magwaza, who is currently a Director of the Tongaat Hulett Group. In line with what would be predicted from the analysis of Nzimande, 'JB joined Tongaat Hulett as an industrial relations consultant (Mail \&Guardian 29/09/00). As the chair of the group's empowerment committee, his commitment is to produce a new black commercial farming elite. The strategy of creating this elite is clearly beneficial to the 
group itself as it adds new suppliers to the group's mills. Other large groups have similar programmes.

Through such programmes-- the Affirmative Action policies of government, procurement policies of government, and other Black Economic Empowerment initiatives--a new nonwhite economic elite is being created in South Africa. For some it is a continuation of progress made before the demise of Apartheid, for others, a result of new actions to create such an elite within the country. However, the significant dividing line here is the move to democracy in 1994. At this point, proactive government policy began to be directed specifically towards the encouragement of a new elite. Adam et al have called this process the "successful embourgeoisement of a liberation movement" (Adam et al, 1997, 167)

The process towards the creation of a political elite has roots beyond the demise of Apartheid. As explained earlier, traditional leaders, and leaders in the homelands were coopted to aid the state in their Apartheid strategy. Through various processes of transition, a political elite has been created in South Africa. On the local governance level, this process culminated in the 1996 local government elections. Durban has been declared a Category A municipality whereby the municipality has "exclusive municipal executive and legislative authority in its area." (South Africa. Constitution, 1996) Fifty percent of Councillors are elected through the political party's proportional representative lists. Thus, voters in the city cast two votes, the first being for a councillor in the ward in which the voter lives, and the other being for the political party of the voter's choice. (Durban Unicity, 2001) An Executive Committee (Exco) serves as political head of the Durban Metropolitan Council. The membership of this Exco is selected according to the number of votes achieved by different parties within the muncipality. Because of the vast powers invested in this Exco, they are in a sense the most conspicuous political elites. The 'newness' of this elite is essentially due to the fact that opportunities now exist for previously excluded individuals. 


\section{Who Are the Elite?}

In terms of decision-making power, there appears to be very little progress in terms of black empowerment. Top management of most of the companies on the Durban Chamber's Top 100 list, remains dominated by the white elite. A notable exception to this is 'JB' Magwaza, from Tongaat Hulett. The other is P. C. September from Rainbow Chicken. It is in the position of non-executive directors where we find more of the non- white elite. However, in terms of strong decision-making power, the balance is clearly in the hands of the white executives. Two notable exceptions to this are A.M. Moolla and the management of the Lion Match Company, which is owned by FASIC. Both of these companies appear on the Financial Mail Top Black-Controlled Firms, 2000, and are 100\% controlled by the Indian elite. We can deduce from this therefore that in terms of the corporate elite, nonwhite individuals have made very little headway, despite strong government initiatives and legislation to challenge this situation.

Government procurement policies are expected to aid the emergence of this elite, particularly in local areas through such policies in terms of tendering. The council spends about R1m a day for basic services procurement. (Interview, Glen Robbins, Unicity Economic Development Department) In light of the fact, discussed elsewhere, that preferences in targeting are given towards Affirmable Business Enterprises and Women Owned Enterprises, we could expect to find that a new elite is emerging because of these preferences. We have thus targeted this process in order to search for the emergence of a new elite. However, this research found that this was not the case. Of the top twenty companies achieving the highest cumulative value tenders in a one-year period, only six were of ABE status. Furthermore, none of these companies were women-owned. None of the directors of these six companies agreed to be interviewed or to provide any information for this research. This prevents us from making any conclusive remarks; however, it does open the doors for a little speculation.

The top ABE company in terms of total tendering amounts is Stedone Emerging Civils. When trying to contact Mr. Dube, the person in charge of this company, it was found that 
his offices are based at the Head Office of Stedone Construction, a non-ABE company. The possibility exists that some of these companies are in fact established in order to by-pass the affirmative action requirements of the council. One respondent summed this up in terms of Sivukile Construction, an ABE company owned by Cyril Gwala.

"He is just there to add respectability. He is actually part of the Grinaker LGA syndicate. One of his companies will be awarded [ a contract for the development of the Point Marine Park] but I don't know how much he is getting himself." (Interview with Don Mkwanazi)

While Sivukile's name does not emerge amongst the council's tendering applicants or award-winners in the year under study, it does suggest that there is a degree of the fronting by ABE companies for traditional white-owned companies happening in Durban. ${ }^{17}$ This is a possible reason why some of the tender awarded companies are reluctant to be interviewed.

The third highest $\mathrm{ABE}$ receiver of tenders from the city was Nascon Projects. They had received some high profile contracts such as the R104-million Durban International Airport renovation contract. However, in the middle of the project, the company had 'gone bust'. (Daily News, 28/2/2001) This company would not agree to an interview. Ian Bell of the Tenders Office of the Unicity administration attributes this kind of situation to some of the $\mathrm{ABE}$ companies overextending themselves and taking on more contracts than they have the capacity to fulfil.[This was confirmed in an interview with M. Hyatt of the property conglomerate Marriott, a major city developer].

Clearly therefore, the stark absence of effective ABE companies emerging out of the tender process hinders elite creation. This is compounded by the fact that there is a lack of capacity to use the contracts awarded to become elite entrepreneurial businessmen, as in the case of Nascon outlined above. If it is the case, as we speculate, that some of the ABE

\footnotetext{
${ }^{17}$ Fronting as a technique has a long history from apartheid days and earlier given racial preferences in licensing of business premises, restrictive housing covenants and the Group Areas Act system.
} 
companies are mere fronts for traditional white businesses, the 'owners' of such companies cannot be seen to have real decision making power--in terms of Dahl's qualification for elite status, for instance. The Affirmative Procurement policy of the council can in the light of this, not be seen to be creating a new economic elite. Conditions for a regime politics of the kind suggested by Clarence Stone are not yet in place. This fact is further underlined by the fact that none of the directors or owners of these companies were listed by the interviewees as having elite status. Thus, they cannot be considered elite according to Hunter's reputation-based criteria. Who then were the elite who emerged from interviews as having such a status?

Three of the interviewees were not prepared to state whom, in their opinion, the elite in Durban were. (Interviews with McCarthy, Brink, Robbins) This will be touched on again a little later in this paper. Others expressed various reservations about naming the new economic elite. However, five respondents gave their opinions of whom they perceived the economic elite in Durban to be. While this analysis runs the danger of being skewed due to the small number of respondents in this regard, it does serve to highlight a few issues around who the reputed economic leaders in the city are. Firstly, there is clearly no cohesive elite grouping in the city. Five respondents named a total of thirty-one new economic elite figures. Of these, the large majority, twenty-five, were mentioned by only one respondent. Three names were mentioned twice and one name mentioned three times. The only two exceptions to this were Don Mkwanazi and Vivian Reddy, who were mentioned by all respondents as being important economic role-players. This can be attributed to a number of reasons. The first is that neither of these two businessmen are entirely 'new' elite in the sense that both have been important players in the business environment for many years. Vivian Reddy, of Edison Power, has been making a name for himself in business for the past fifteen years. He has built his company up and in that time has acquired contracts to the value of R1 billion. (Hart \& Padayachee, forthcoming, 705) He is majority owner in SAM Sisonke, a Malaysian and South African Joint Venture, and is also involved in the Sugar Mill Casino outside of Durban. (Ibid., 706) Similarly, Don Mkwanazi has been working around issues of business, especially in areas of Black 
Empowerment for as many years. His reputation as a business leader can largely be attributed to his reputation as such more than his business activities. He has been involved in the African Chamber of Commerce, has been an advisor to the DCC since the 1980s, and was a senior economic advisor to the ANC. Furthermore he was the manager of the Black Management Forum for many years. (Interview,Don Mkwanazi) ${ }^{18}$ Their reputation as business leaders is also bolstered by their involvement in business initiatives such as DIPA

Hart \& Padayachee noted that the ability to form alliances with the new regime is an important determinant of the success of, in particular Indian businesses. "Besides being well connected to the highest echelons of the ANC, Vivian Reddy makes sure that the Zulu King and Chief M. Buthelezi, the Inkatha leader, are prominently associated with his businesses." ( Hart and Padayachee, forthcoming, 706) Mkwanazi also acknowledges the importance of such links. With strong links to the ANC leadership, he also has links to Inkatha, important in a business environment in KwaZulu/Natal. "I also happen to be very close to the King of Zululand." (Interview, Mkwanazi)

Neither of these two elite members are products themselves of affirmative action. This, as the interviews showed, is an important factor towards contributing towards a positive assessment of being an elite. There appears to be, amongst the respondents surveyed, a sense of disdain towards elite status achieved through this method. Conversely, there is great admiration towards elite status achieved despite barriers placed by apartheid government. This fact is firstly displayed by the fact that only two respondents suggested 'JB' Magwaza as a member of the economic elite. This is despite the fact that he receives wide media coverage in his empowerment programmes, and is an executive member of a

\footnotetext{
${ }^{18}$ His reputation might not only come from positive business involvements. Mkwanazi gained large-scale media coverage for his allegedly corrupt practices while chair of the Central Energy Fund, and for his subsequent suing of the Mail and Guardian for articles relating to this scandal. (Mail and Guardian 19/02/2001)
} 
very powerful corporate business, Tongaat Hulett. Comments from respondents further back this up;

"What we like about them is that they have worked. These names that I have just mentioned, they are not a product of empowerment. They have just worked for whatever they have got. This thing of affirmative action is a thing for yesterday. They have already been there, they were already there before affirmative action took place" (Interview, Mile)

It is clear from this research that in terms of reputation, the new entrepreneurial elite are considered more important. But, in terms of decision-making, especially with regard to decisions around the development of the city, who is most important?

There is very little argument among the respondents that although there is an emergence of a new elite, the real power still lies with the traditional white elite.

\footnotetext{
"The white elite have been in control all along" (Interview, Don Mkwanazi) "I just think that their size and the importance of their role means that they are a voice that does have an impact" (Interview, Lyn Ploost van Amstel, opposition leader in Council)
}

In particular, Mondi and Tongaat Hulett are seen to be the important players. As such, the Durban business community is seen to be relatively untransformed. (Interview, Robbins) Robbins attributes this to the satellite nature of the Durban companies. While restructuring occurs at the head offices in Johannesburg, he feels that it has not significantly filtered down to the satellite offices in various parts of the country. Thus, the major corporate entities exert powerful influence in the city be virtue of their size, and the control of these companies remain in the hands of the white elite. However, most respondents do not feel that this is necessarily a bad thing. 
"Yes, it is still dominated by the white males in particular by virtue of them being in business for quite some time. There is no short way to buy experience. The only way to buy experience is by being exposed.....we still remain dominated...it will take time, a 40 year forecast building the individuals, but, we will get there." (Interview, Nozipho Sithole)

Other respondents emphasised the important experience that the white elite could offer, saying that if this were lost, it would negatively impact on the economy of Durban. (Interviews, Mile, Sithole) However, some respondents, in acknowledging the continued dominance of the white elite, highlighted the potential negative implications of this fact.

"This has been one of the issues of conflict between the ANC and the business community; there hasn't really been a sense that Durban traditional businesses have taken the lead in transforming themselves to become the new vehicles of empowerment, which is what the ANC would have looked for" (Interview, Glen Robbins)

This lack of a cohesive agenda presents a significant stumbling block for coalition forming for the economic development of the city. However, the city is not entirely devoid of cooperation between big white business and new black business for the development of the city. Nor is it devoid of interactions within the black elite, both political and economic. Who then are the political elite?

The ANC is dominant as a political party in Durban, and holds five seats in Exco including that of the Mayor, the Deputy Mayor, and the Speaker. The IFP holds two seats, as does the DA. The Minority Front, which represents a section of Indian opinion, holds one seat. The DA was supposed to receive more seats, but a coalition between the ANC, IFP and the MF allowed the Exco to reduce the total number of seats, thus diminishing the effective power of the DA as the largest opposition group. (Interview, Ploost van Amstel) This marginalisation of the DA is also seen by the fact that that the two DA Exco members are 
the only Exco members not to have a Chair on a Portfolio Committee. The backgrounds of the Exco members are diverse. The Mayor and the Deputy Mayor have strong business backgrounds. Two other members have business involvements. Four of the Exco have strong backgrounds in politics and two of the members have education as the primary focus in their backgrounds.

There is a historical background that lays the basis for black economic and political interaction amongst the elite.

"Largely, we come from the same background of being educated in the townships and gone to varsity together. Some are fellow church members and there is a certain level of interaction on those different levels. But, then again, I think that the Durban business community is a small one so every black businessman has a pretty good idea of who does what in other spheres of business. Therefore, there is a growing business brotherhood out there." (Interview, Gwala)

Despite the particularly brutal violence that occurred in the latter days of Apartheid, this interaction seems to cross party lines. Mile attributes this to the fact that the new black elite comes largely from the same areas, and are, in a sense, family. The extent of this cohesion however, is questionable. The degree to which economic leaders were nominated, in particular, along racial lines, and to a lesser degree, on party political lines, is significant. Robbins attributes this black elite interaction to be more based on economic and 'power in numbers' principles.

"Black entrepreneurs feel that they need to co-operate to access opportunities that are there. They often feel that they are the small brothers and sisters of the bigger black empowerment initiatives in Johannesburg. For example, Tongaat Huletts is in the process of unbundling, and no-one locally has the finance to purchase that interest. So, they have to go to Johannesburg to hunt the finance, they have to go 
to the bigger empowerment consortiums in order to reach critical mass to play these critical roles." ( Interview, Robbins)

He goes on to assert that the coalition of black business in Durban is relatively weak. As other interviewees agree, this coalition is particularly weak in the light of the persistent dominance of the white controlled big business in Durban. However, the political make-up of the Unicity Exco created in 2000, does to a degree facilitate greater co-operation between the elites in the city. Most of the emerging young innovative black businessmen that are emerging in the city have a very strong alignment with the ANC. This confers a degree of power to the black elite which is largely beyond the reach of the white economic elite. Importantly, access to the city is made easier. (Interviews, Robbins, McCarthy)

This paper now moves on to examine this relationship between the economic elite and the political elite in more detail. Specifically, this is in terms of the economic development of the city. The integrated and pervasive powers of the traditional white economic elite have been examined above. So too, has the emerging influence of the new elite. The examination that follows is thus one to determine the nature of these relationships. Firstly, why are the political elite extending their traditional roles of service and infrastructure provision to one where they are interacting more with business to encourage economic growth?

There is little doubt that economically the city is in dire need of attention. This was agreed to by all respondents and put across clearly by the Monitor Report. The implication that this has for any would-be rulers of the city are serious. Glen Robbins from the Economic Development Department, cites two reasons for this involvement of the political elite in economic processes.

Firstly, he attributes it to the national and regional emphasis on achieving growth and the explicit calls for this to be encouraged through local government. In particular, this is necessary for employment creation in addressing the historically disempowered electorate. The other important reason is the need for local government to maintain sustainability. 
Most of government income is generated through taxing businesses. "About $68 \%$ of all income generated by local government comes from industrial or commercial sources, either through the rates on their properties or though a special business levy, or through the profits we make on supplying them with water and electricity." This was not a particularly difficult task in the past, well within the financial scope of the city. However, as part of the mandate from government, the city is now required to extend its services to previously disadvantaged people in a much wider geographic region in terms of the new city boundaries. "For example, in the last seven years, the council has escalated its expenditure programme by about 300 to $400 \%$. That means that we've had to generate an additional $300-400 \%$ income. It is thus imperative to then get the growth that will then fund that expenditure."

What forms are these interactions taking? The most significant of these is the newly-created Durban Investment Promotion Agency (DIPA) The primary goal of this agency is to try and promote investment in the city. This emerged from the recommendations of the Durban Best Practice City Commission. This commission was set up at the behest of the city to come up with recommendations about what interventions were required to make Durban a preferred investor destination. Neels Brink (Moreland), Cyril Gwala, (Sivukile Construction) and Themba Ngcobo were among the ten commissioners. The board and CEO of DIPA has just been elected and they should be up and running by the beginning of January. The rationale behind the Agency is that the treatment of investors in the city was not very good, and thus did little to encourage them to invest in the city. Robbins considers this initiative to be an important private-public initiative between council, white and black business.(Interview, Robbins) Other observers however, question the capacity of the people on the board to achieve the gains, saying that the appointments are more political in nature than anything else. (Interview, white business representative).

A second important, and very recent, initiative, which involves both the private sector and the public, is the imminent development of the Point Waterfront. The development of this valuable land has been on the cards for many years but has continuously been stalled. 
However, the concept and plans were launched on 17 October 2001. In the planning and negotiating stage, the white elite, in the form of Neels Brink (Moreland) played an important role. Cyril Gwala, (Sivukile Construction) was the deputy director of the project team. The council has allocated R350m of its equity funding for this project, and the remainder of the R650m is being sourced from other funders with the city government itself being thus the major stakeholder. (Interview, Brink) Brink considers this project as an important three way mix in term of partnerships. "Public local government, parastatals, the Development Bank and the Industrial Development Corporation and then private banks" (Idem.)

Clearly, there is therefore a strong interaction between the economic and political elite in the city of Durban. What remains to be done in this research is to investigate further the extent of this interaction. Do we have a growth coalition in the city?

There are numerous references in the media to the 'Durban Growth Coalition' as though it did indeed exist John Barton ${ }^{19}$, in his opening address for the Second Durban Economic Growth Summit, welcomed the members of the "growth summit". But, is the interaction occurring in Durban a growth coalition according the theoretical frameworks established earlier in this thesis? The defining conditions for a growth coalition, as laid down by Dahl are; a distinctive policy agenda that is relatively long term, which is sustained by a coalition of interests that is not institutional, often with cross-sectoral or institutional boundaries. Furthermore, it should be able to survive despite changes in political leadership and should mobilise external resources through means such as public-private Partnerships. (Dowding, 2001, 14)

There is no doubt from the evidence gathered that there is a degree of interaction between the political and economic leadership in the city. While there are limits to the extent of this interaction, the basis is being laid for further interaction. Not least amongst the various

\footnotetext{
${ }^{19}$ Chair, Mondi Paper Company and CEO of the Durban Chamber of Business, a far more dynamic agency than the old Chamber of Commerce which typically represented small downtown businesses.
} 
forums that are being developed or expanded upon,is the Durban Business Vision (largely created by the Chamber of Business), the DIPA and the Durban Economic Growth Summit. Interactions around these initiatives are involving business, both black and white, local government, provincial government and other stakeholders. Furthermore, interactions through well-established structures such as the Durban Chamber of Business, continue. Dahl discusses a coalition of interests that are not institutional. The forums mentioned above are institutional, and the policies emerging form this are consequently institutional too. What mattered to Dahl were the non-institutional policy agendas, the informal relations that would emerge as critical from a Coase derived new institutional economic framework and which are highlighted by Stone in his theory of a regime politics. Thus, we can surmise that a strategic agenda of both private and public bodies is required that are moving in the same direction for a growth coalition promoting regime politics to be fully operative.

Glenn Robbins, in denying the existence of a growth coalition, states that this is not the case in Durban, considers:

"I don't think that there is sufficient actual co-operation and alignment between the work of local government and key businesses at the moment to say that they are a coalition. There are a few projects that have emerged that have their origins before that process began and some of them are from that process. But, projects do not constitute a coalition. They could be the building blocks for something in the future, but there is still not a sense that government has given up or begun to share strategic power with the business community in that sense which is what a growth coalition is about, a kind of strategic power sharing arrangement where commitments are made around budgets, projects and points of focus and objectives, where parties agree and contribute to the process. So far, it has been business, both black and white, saying that this is what we want, what can we help to get council to give us what we want rather than trying to share the programme, and commit business to it in terms of their own resources and commitments." 
In terms of the political elites, the general focus is similar to that of business. Both are looking for a growth-oriented strategy for economic development. Or, as Don Mkwanazi puts it, "sustainable economic growth to increase the cake. If you don't increase the cake, equitable participation of all the citizens of Durban will not happen". There is consensus here about the direction to be followed. However, the fact that the political elite are following this long-term, growth oriented strategy is not without its potential problems and has the potential to upset the political leadership in the city. ( Interviews with Ploos van Amstel, Mkwanazi)

Ploos van Amstel explains that the mayor and the deputy mayor, in particular, are very much for the approach that is currently been taken towards economic growth. They are both from a business background and many of their policy directions are based on concerns raised in the Monitor report. However, as she goes on to explain, this is not without major challenges raised from within the ANC caucus to these policies. The budget prioritisation for this year is tipped towards long-term economic growth.

"But, there was a lot of resistance, particularly from the ANC caucus, but from a whole range of political parties to the emphasis on investment in economic infrastructure. They mayor got away with it this year but I don't think that he will be able to in future years. There is certainly a very vocal group within his party saying that they do not like what he is doing."

While business on the whole is very happy about the direction that the mayoral policies are taking, the citizens, or more particularly the mass of voters, clearly do not share these views. The implication is that the political elite might not survive the challenges that might emanate from such emphasis on economic growth. This brings us back to the requirements of Dahl for a growth coalition. It remains to be seen if a change in leadership will allow the coalition, if indeed there is one, to proceed. 
There is clearly interaction between the political and economic elite in Durban that could form the basis for a vision that is structured around economic growth. Because there is not yet the strategic joint making decisions, however, it cannot yet be termed a growth coalition in our view despite numerous references in the forums around economic development. What is the potential for the groundwork to become a power-sharing coalition, a regime in Stone's sense?

The first hindrance must be the fact that the important economic players in the city are still those from the white owned and white controlled businesses. While not explicitly stated by any of the respondents, the continuing lack of consensus between white business and local government, must be a hindrance to this process. The other reason, tied in to this, is the lack of a cohesive black economic elite grouping, as discussed earlier in this paper. Robbins states that the grouping that exists in inadequate in terms of cohesion, and also in terms of lacking a dynamic leadership to drive the process forward.

Both of these factors are potentially positive however. Robbins explains that coalition forming is to a degree hindered by the nature of big white business, and this can be overcome by the coming to the fore of the smaller, locally based, non-white businesses.

"We have many huge challenges, both social and economic. This could have very significant benefits in creating a period of alignment. What we have in terms of the most powerful business interests are people with a profile of business activities in traditional sectors of the economy. But, the economy is rapidly changing. Our important players [at present] are Anglo-American players around the table in terms of Mondi and Tongaat Hulett, both commodity centred businesses... In ten years time, the world is going to change very much. If you look at some of the coalitions that have been successful elsewhere, they have not had their foundations on the 'biggest is best approach'. It has often been those businesses that are on the cusp of growth opportunity who show more innovation and have a sustained interest in the 
growth of a particular place and a commitment to that place. One of the things that needs to be confronted is that you need a leadership team who are going to be very important in the economy in the future. They are the most important right now. You need to catch them at the right time." (Interview, Robbins)

One needs also perhaps to mention another limitation. In the former regime, city bureaucrats, especially heads of key departments, themselves formed an elite critical for making policy and considering agendas that were critical to the development of the city. While the new government has now been in power for several years, the transformation of City Hall is far from complete and the seats of the bureaucrats are now occupied far more uneasily. It is no longer possible for bureaucrats to manipulate or control politicians as was to some extent previously the case. Even talented figures such as Glenn Robbins have to function mainly as facilitators, or intermediaries between elites, for the time being. Of course, this situation may shift with time. It is less clear whether the absence of a bureaucratic elite of real potency makes the pursuit of a development regime more difficult or, beyond limits, even impossible.

\section{Conclusion}

This study can be used to suggest both positive and negative aspects of the current Durban elite as a touchstone for economic development along the lines suggested in the Monitor report. On the negative side there is the very fragmented nature of the elite, divided by race and politics. The bureaucracy, which ascended to unprecedented power from the 1960s, is in a state of disarray in the context of political transition, particularly with the establishment of the Unicity in 2000. For the moment, it is no longer able to play a guiding role in the shaping of the city. In addition, the new black elite remains weaker and smaller by far than the white corporate elite. It lacks self-confidence in some respects and it tends to participate in, rather than to plan, those civic initiatives of interest to the business world. By contrast with Stone's Atlanta, where a black business elite has been able to formulate plans to enrich 
themselves significantly while retaining enough political capital to get the votes of a largely poor and disadvantaged electorate, the equivalent group in Durban is still tentative. ${ }^{20}$

Both of our white business interviewees suggested that private-public partnerships are still at a modest state of development. One can hardly talk about a corporate elite that crosses the public-private divide and the racial divide in fixing plans for the future of Durban. Environmental issues as well as the poverty alleviation and delivery strategies critical to the hearts of the politicians are seen as separate from, or even in conflict with, developmental needs rather than being part of a negotiated, holistic strategy. (see Bond, 2000; Freund, 2001)

In addition, much of the elite achieves power, status and significance through provincial and national, rather than local linkages, and does not so clearly form ties within the city of primary importance. While political linkages are of critical importance to this elite, it cannot be said that the tendering process, which shows the direct potential of local state patronage, is exerting a very important influence in elite formation. On the positive side, the sense of new players with links to the new South Africa and the potential to take up different kinds of initiatives than the existing elite is also significant as is the emergence of individuals who are able to serve as intermediaries and brokers between different segments of the elite. A number of such individuals can be found both in the local state and in the private sector. There is a strand of co-operation that has developed in Durban starting with the tentative negotiations of the political transition period of the early 1990s, through the successful construction of the International Conference Centre, financed by City Hall to the present plans for constructing a massive tourist complex at the Point (Shaka Island). The Durban Vision statement of the Chamber of Business, which now enlists the energies of the big corporate players in a way that the previous Chamber of Commerce did not, focuses on tourism and transport issues but seems to unite a broad cross-section of elite opinion and the formation of the new Investment Advisory Commission, formed following the

\footnotetext{
${ }^{20}$ In Atlanta, they colluded between the 1940s and 1960s in "urban renewal" programmes that pushed nearly 70.000 citizens, almost all black, from the vicinity of the centre city.
} 
recommendations of the corporate-dominated but civic-created Best Practice Commission, suggest at least a broad consensus of elite opinion. A feature of these structures is that they have a tendency to modify the centripetal tendencies of capital in Durban. The pull of capital is towards the urban periphery. Capital constructed the Pavillion shopping mall in Westville a decade ago and has recently created the giant, US designed Gateway Mall in the midst of a large section of expensive housing and new office construction. Still further out is the new planned airport at La Mercy. (See Map One) By contrast, schemes with direct local state involvement such as the ICC conference centre and the proposed massive investment at the Point are centrifugal, aimed at bringing money to the edge of the historic and now declining CBD. These schemes and processes remain largely dependent on the creative initiative of the old elite, however; we still await the emergence of a new configuration, an effective "regime politics" of the kind envisioned in some of our interviews. Still less clear is the extent to which such a growth coalition would be any more willing than its American equivalents to provide the basis for social and human potential development as well as to right the capitalist accumulation process for Durban.

\section{BIBLIOGRAPHY}

Adam Heribert et al, (1997) Comrades in Business, Cape Town,Tafelberg.

Amin Ash, editor (1994) Post-Fordism; A Reader, Oxford, Blackwell.

Bennett Larry, editor, (1988) “Chicago's North Loop Redevelopment Project: A Growth Machine on Hold" in Cummings.ed., op.cit., pp.183-204.

Berle A A., (1954), The Twentieth-Century Capitalist Revolution, New York, Harcourt Brace.

Bjorvig Anna Christina (1994), "Durban 1824-1910", PhD thesis, University of Natal, Pietermaritzburg.

Bond Patrick, (2000), Cities of Gold, Townships of Coal: Essays on South Africa's New Urban Crisis, Trenton / Asmara, Africa World Press.

Bredeloup Sylvie (2000) Abidjan: un dispositif marchand en mutation”, Three Cities Conference proceedings, University of Durban-Westville, 20-24 November. Burnham James (1941) The Managerial Revolution, New York, John Day. 


\section{Business Day - various}

Caro Robert (1975) The Power Broker; Robert Moses and the Fall of New York City_New York, Vintage.

Castells Manuel (2000) The Information Age; Economy, Society and Culture, Oxford, Blackwell, second edition.

Coase, R.H., (1937), “The Nature of the Firm”, Economica vol. IV(16) N.S., pp.386-405. Cummings Scott (editor), (1988) Business Elites and Urban Development: Case Studies and Critical Perspectives, Albany, State University of New York Press.

Dahl Robert (1961) Who Governs? Democracy and Power in an American City,_New Haven, Yale University Press.

Daily News (Durban) - various

Dowding K (2001) “Explaining Urban Regimes”, International Journal of Urban and Regional Research, vol. XXV, pp. 7-19.

Durban. Metropolitan Council (1999) Enterprise Registration Affidavit (Affirmable Business Enterprises).

Durban. Unicity (2001): Towards a Long Term Development Framework for Durban Unicity: An Overview of the Key Developmental Challenges, Unicity Vision, Outcomes and City Strategy.

Evans Peter (1979) Dependent Development; The Alliance of Multinational, State and Local Capital in Brazil, Princeton, Princeton University Press.

Ferman, Barbara (1996) Challenging the Growth Machine; Neighborhood Politics in Chicago and Pittsburgh, Lawrence, University Press of Kansas.

Financial Mail (Johannesburg) - various

Freund Bill (forthcoming) "City Hall and the Direction of Development: The Changing Role of the Local State as a Factor in Economic Planning and Development in Durban" in Freund \& V.Padayachee, The D(urban) Vortex, Pietermaritzburg, University of Natal Press. 
Freund Bill (2001), "Brown and Green in Durban: The Evolution of Environmental Policy in a Post-Apartheid City", International Journal of Urban and Regional Research, vol XXV, 4, pp. 717-39.

Galbraith John Kenneth (1971) The New Industrial State, London, Andre Deutsch, $2^{\text {nd }}$ edition.

Giddens, Anthony (1981), The Class Structure of the Advanced Societies, London, Hutchinson.

Hall Peter (1986) Governing the Economy; The Politics of State Intervention in Britain and France, Oxford, Polity.

Hart, Keith \&Vishnu Padayachee, (forthcoming), "Indian Enterprise in Durban, South Africa: Local and Global History in the Long Twentieth Century", Comparative Studies in Society and History.

Hatch John (1965) A History of Postwar Africa, New York, Praeger.

Healey P (editor) (1995) Managing Cities: The New Urban Context, London, John Wiley \& Sons.

Herron Jerry (1993) Detroit and the Humiliation of History, Detroit, Wayne State University Press.

Hunter F (1963) Community Power Structures, New York, Anchor Books.

Jessop Bob (1982) The Capitalist State, Oxford, Basil Blackwell.

Keil Thomas (1988) "Disinvestment and Economic Decline in Northeastern Pennsylvania:

The Failures of a Business Elite's Growth Agenda" in Cummings (editor), op.cit., pp. 26998.

Landes David (1965) “Japan and Europe-Contrasts in Industrialization” in William Lockwood (editor) The State and Economic Enterprise in Japan, Princeton, Princeton University Press, pp.93-182.

Logan, John \& Harvey Molotch (1987) Urban Fortunes, Berkeley, University of California Press.

Macozoma S (2000) "The Elite: Eyes on the Prize-- A Touch of Class, Fortune and Privilege in South Africa”, Financial Mail, Holiday Edition Supplement, 'December 8-15. 
Maharaj B \& Rambali K (1996) "Recent Trends in Local Economic Development in the United States. Policy Implications f or Urban Development in South Africa", Urban Forum, vol VII no.2, pp. 159-82.

Mail and Guardian (Johannesburg) - various

McCarthy Jeffrey (2001) “The Restructuring of Business in Durban”, Three Cities

Conference proceedings, University of Durban-Westville, November 20-24.

Mercury (Durban) -various.

Metro Beat Magazine(Durban) - various

Miliband Ralph (1959) The State in Capitalist Society; The Analysis of the Western System of Power. London, Weidenfeld \& Nicolson.

Mills C Wright (1956) The Power Elite, New York, Oxford University Press.

Mollenkopf John (1983), The Contested City, Princeton, Princeton University Press.

Molotch Harvey (1988) "Strategies and Constraints of Growth Elites" in Cummings, (editor) op.cit., pp.25-48.

Monitor Group \& Durban Unicity (2000) Durban at the Crossroads.

Nzimande, E B, (1991) “The Corporate Guerrillas: Class formation \& the African

Corporate Petty Bourgeoisie in Post 1973 South Africa”, Ph.D. University of Natal,

Durban.

Padayachee, Vishnu (forthcoming), "Financing Durban's Development" in Freund \&

Padayachee, (eds.), The D(urban) Vortex, Pietermaritzburg, University of Natal Press.

Purcell, John, (1974), “Durban, South Africa: Local Politics in a Plural Society”, Ph.D

thesis, University of California, Los Angeles.

Parry G (1969) Political Elites, London, George Allen \& Unwin.

Pillay U (1994) 'Local Government Restructuring, Growth Coalitions and the

Development Process in the Durban Functional region 1984-1994”, Urban Forum,_vol.V, pp. 59-86.

Pillay U (1996), "The Uniqueness of Locality - The Case of the Durban Functional Region”, Urban Forum, vol. VII, pp.32-52.

Robinson J \& C. Boldogh (1994) “Operation Jumpstart: An Urban Growth Initiative in the Durban Functional Region" in R. Tomlinson, op.cit. 
South Africa (1996) Constitution.

South Africa (2000) Municipal Systems Bill

South Africa (1998) Municipal Structures Act

South Africa (1998) White Paper on Local Government.

Stone Clarence (1989), Regime Politics; Governing Atlanta, Lawrence, University Press of Kansas.

Tomlinson R (editor) (1994) Urban Development Planning: Lessons for the Economic Restructuring of South African Cities Johannesburg, Witwatersrand University Press. Useem Michael (1984), The Inner Circle; Large Corporations and the Rise of Business Political Activity in the US and the UK, _New York, Oxford University Press.

World Bank (1991)

\section{Oral Sources:}

a.

Presentations made to the $2^{\text {nd }}$ Durban Economic Growth Summit, 11 June 2001 by Don Mkwanazi, Michael Mabuyakhulu, Sbu Ndebele, David Wightman.

\section{b. Interviews conducted with:}

Neels Brink - Moreland Property, Tongaat-Hulett.

Cyril Gwala - Sivukile Construction, DIPA

Mike Hyatt - Marriot Merchant Banking

Mina Lesoma - African National Congress

Jeff McCarthy - Professor, Graduate Business School, University of Durban-Westville Johannes Mile - Inkatha Freedom Party

Don Mkwanazi -DIPA

Gladwin Ndlela - Inkatha Freedom Party

Lyn Ploos van Amstel - Democratic Alliance councillor.

Glen Robbins - Unicity. Economic Development Department

Nozipho Sithole-Port Manager, Port Authority, Portnet [parastatal]

Ahmed Sadek Vahed - AM Moolla Co. 


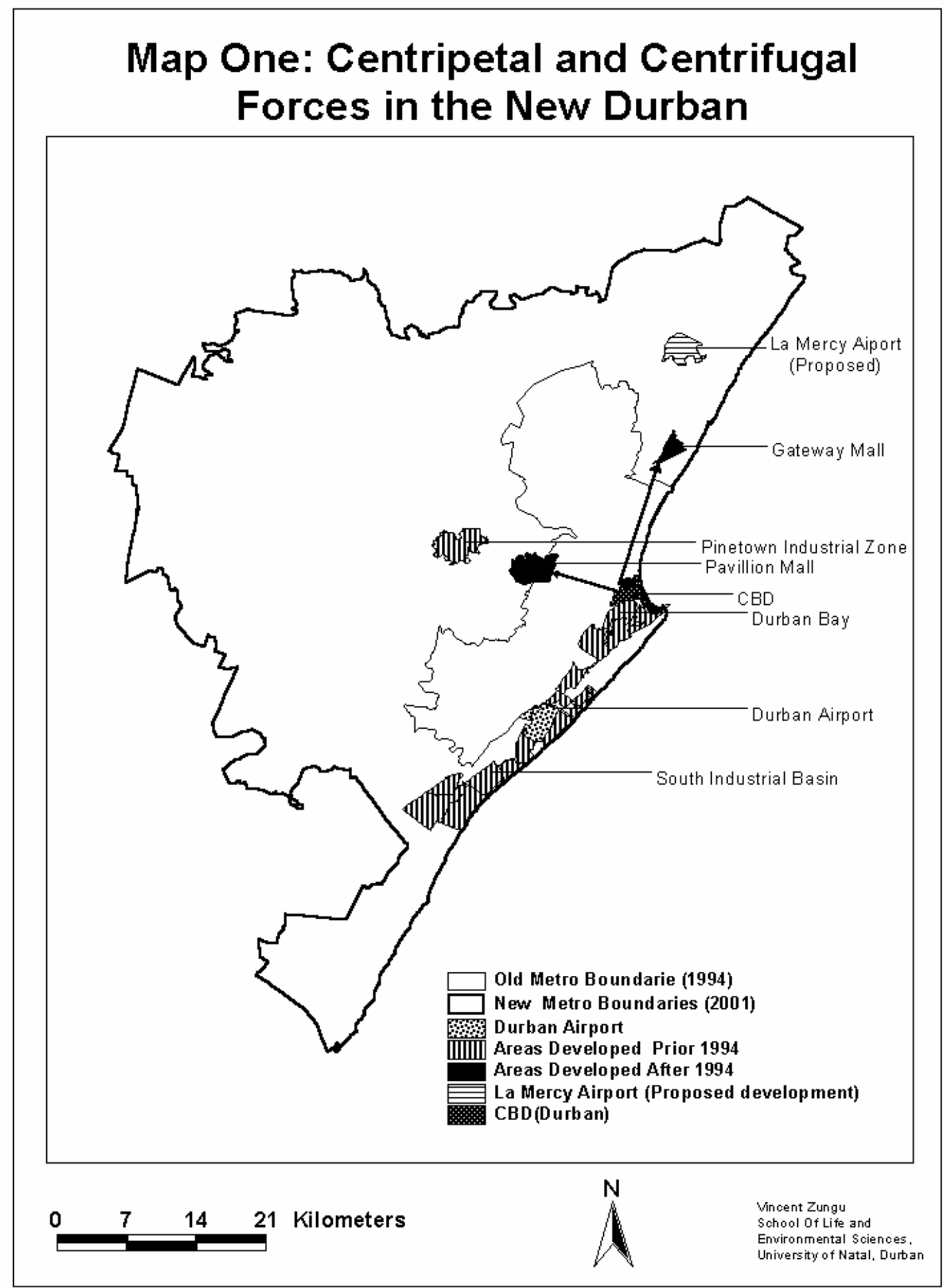




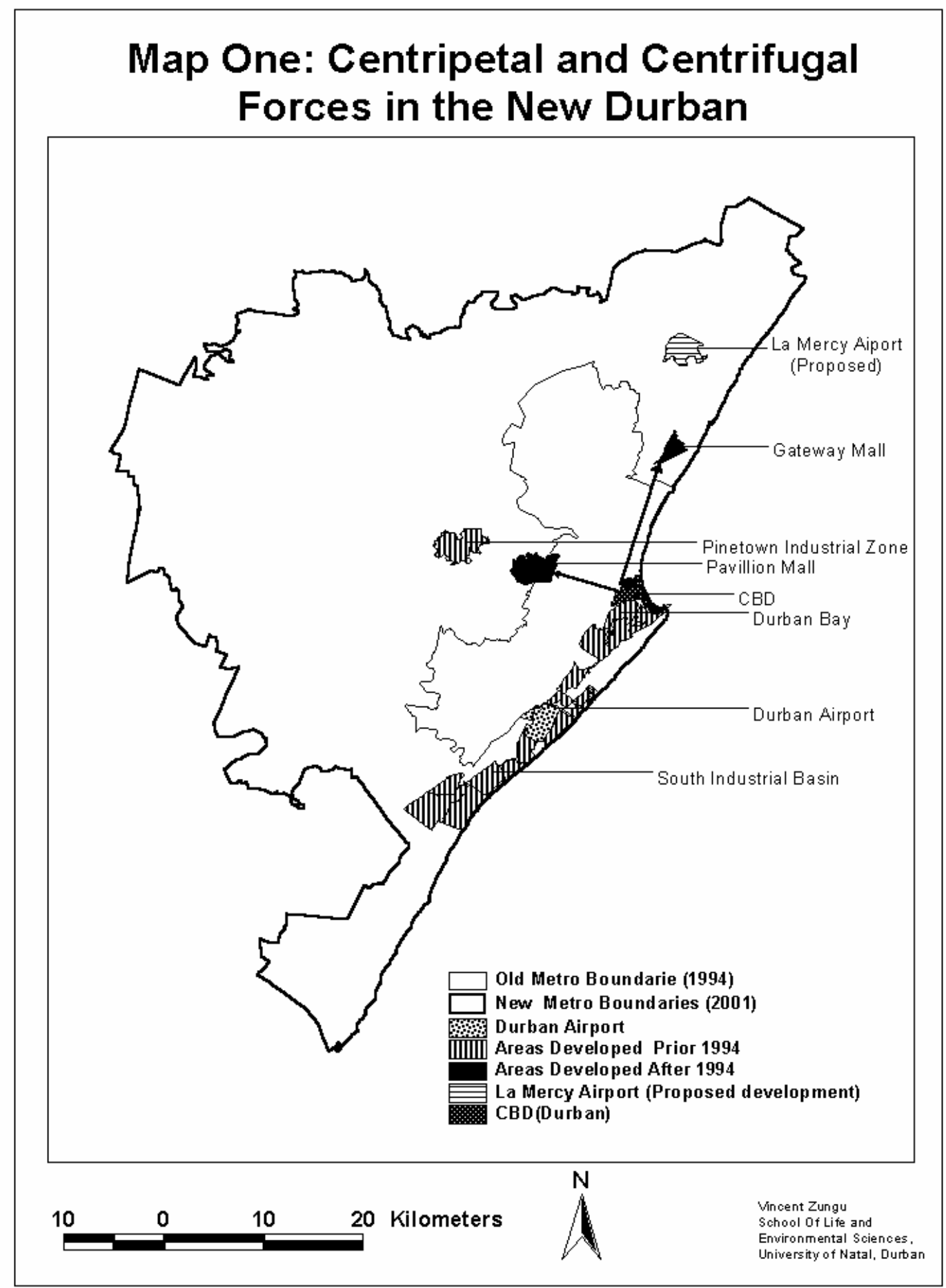


